\title{
Molecular phylogeny of the Neotropical fish genus Tetragonopterus (Teleostei: Characiformes: Characidae) ${ }^{\text {th }}$
}

\author{
Bruno F. Melo ${ }^{\mathrm{a}, *}$, Ricardo C. Benine ${ }^{\mathrm{b}}$, Gabriel S.C. Silva ${ }^{\mathrm{a}}$, Gleisy S. Avelino ${ }^{\mathrm{a}}$, Claudio Oliveira ${ }^{\mathrm{a}}$ \\ ${ }^{a}$ Departamento de Morfologia, Instituto de Biociências, Universidade Estadual Paulista, Botucatu, São Paulo, Brazil \\ ${ }^{\mathrm{b}}$ Departamento de Zoologia, Instituto de Biociências, Universidade Estadual Paulista, Botucatu, São Paulo, Brazil
}

\section{A R T I C L E I N F O}

\section{Article history:}

Received 3 September 2015

Revised 14 October 2015

Accepted 19 October 2015

Available online 2 November 2015

\section{Keywords:}

Amazon

Freshwater fishes

Historical biogeography

Multilocus analysis

Tetragonopterinae

\begin{abstract}
A B S T R A C T
Tetragonopterinae encompasses characid species of the genus Tetragonopterus, which are widely distributed throughout east of the Andes in South America. While taxonomy has recently clarified the species diversity and molecular evidence strongly supports the monophyly of Tetragonopterus, no interspecific relationship studies are currently available. Here we used a large molecular dataset composed of two mitochondrial and three nuclear loci containing an extensive taxon sampling within the family Characidae and included eleven species of Tetragonopterus to generate the first time-calibrated phylogeny for Tetragonopterinae. Our results support monophyly of the subfamily represented solely by Tetragonopterus and corroborate previous molecular hypothesis of close relationship with Exodon plus Roeboexodon and the subfamily Characinae. Internally, we found Moenkhausia georgiae as sister species to all remaining species followed by $T$. rarus, being both species endemic to the Guiana Shield drainages. Species-level relationships are first hypothesized and putative morphological apomorphies are discussed as support to monophyletic clades. Our time-calibrated phylogeny suggested an origin of the genus during the Late Oligocene-Early Miocene. We hypothesized that the Andean geological activity followed by transformations in the Amazonian hydrographic scenario during the Miocene may have promoted most of the lineage diversification within the Tetragonopterus.
\end{abstract}

(c) 2015 Elsevier Inc. All rights reserved.

\section{Introduction}

The Neotropical fish genus Tetragonopterus Cuvier, 1816 (Fig. 1) is widespread throughout the main South American river basins (Orinoco, Amazon, São Francisco and La Plata) and occurs additionally at the rivers systems of Guyana, Suriname, and French Guyana, and the major rivers from northeastern Brazil (Silva et al., 2013). Two synapomorphies have been proposed to define Tetragonopterus: the presence of only three supraneurals and a branched laterosensory canal in the sixth infraorbital (Mirande, 2010; Melo et al., 2011). In addition, several morphological features have been used to diagnose species of Tetragonopterus, such as the compressed and very deep body with a flattened prepelvic region, premaxillary teeth in two rows (inner row with five teeth) and a complete lateral line distinctively bent downward anteriorly (Silva et al., 2013).

\footnotetext{
This paper was edited by the Associate Editor G. Orti.

* Corresponding author at: Dept. Morfologia, Instituto de Biociências, Universidade Estadual Paulista, Distr. Rubião Jr. s/n, 18618-970 Botucatu, SP, Brazil.

E-mail address: melo@ibb.unesp.br (B.F. Melo).
}

Tetragonopterus was the former recipient of most small characin species that were later distributed to several new or already available genera (e.g. Eigenmann, 1903, 1908). These actions restricted Tetragonopterus to four species (Eigenmann, 1917) and, more recently, only to $T$. argenteus and $T$. chalceus (Reis et al., 2003). Last two decades saw an increasing number of contributions involving the alpha taxonomy and composition of the genus (Benine et al., 2004; Melo et al., 2011; Silva and Benine, 2011; Silva et al., 2013; Araujo and Lucinda, 2014) including an extensive taxonomic revision integrated with DNA barcoding (Silva et al., in preparation). Aside the well-studied alpha taxonomy of Tetragonopterus, the phylogenetic relationships with other genera of the Characidae remain unclear. The available morphological hypothesis suggested Tetragonopterus closer to Stethaprioninae, Gymnocorymbus and Stichonodon (Mirande, 2010) and, alternatively, the molecular hypotheses placed it as closer to Characinae and relatives (Javonillo et al., 2010; Oliveira et al., 2011).

Within Tetragonopterus, taxonomic studies associated with DNA barcoding found three well-supported mitochondrial lineages: $T$. rarus, $T$. argenteus and the large $T$. chalceus group with six species (Melo et al., 2011; Silva et al., 2013). Although some putative arrangements were discussed, these studies however did not 

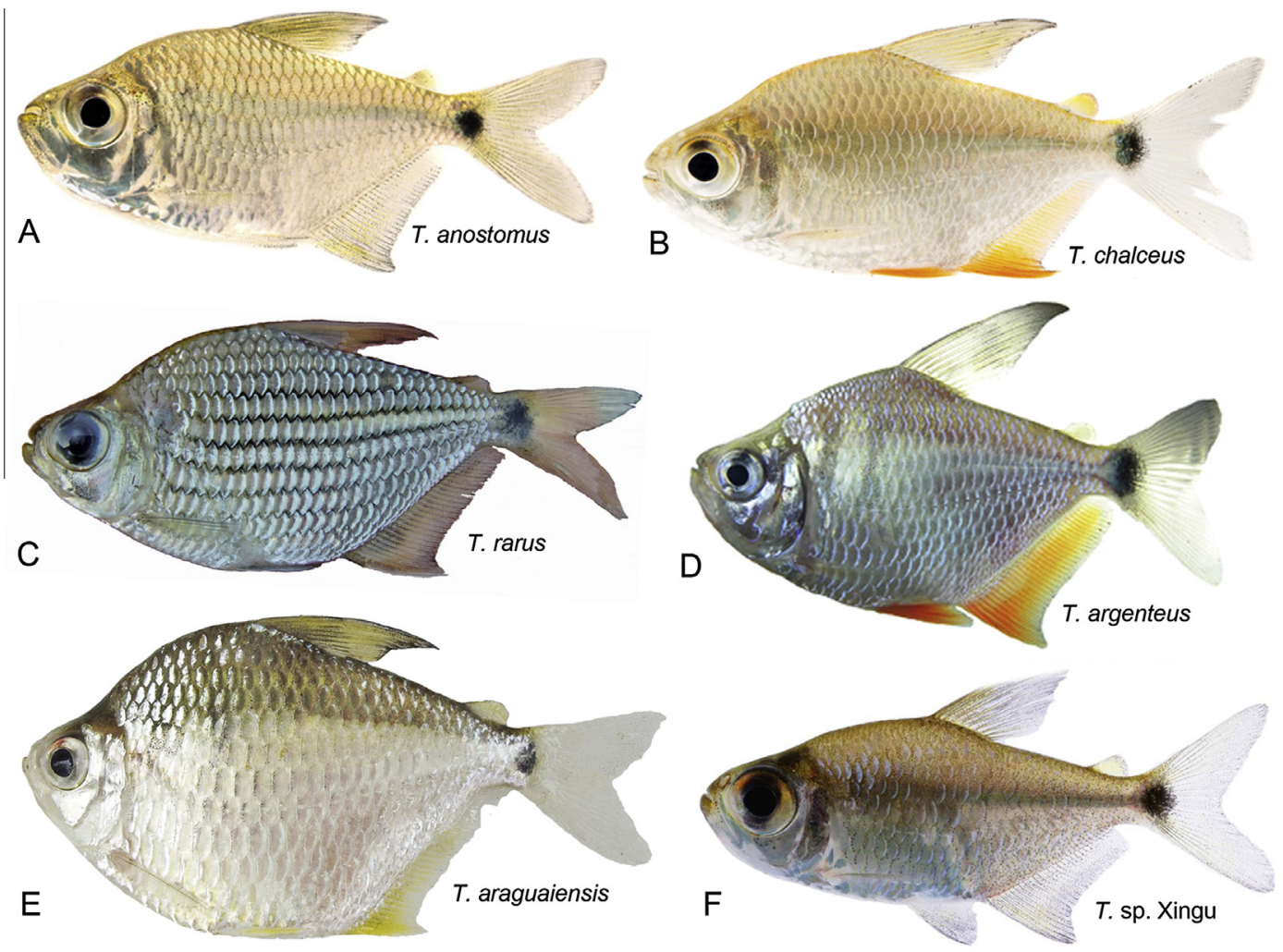

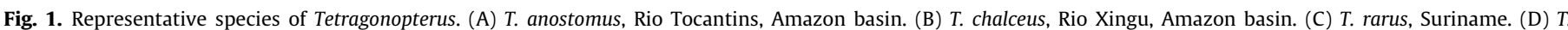

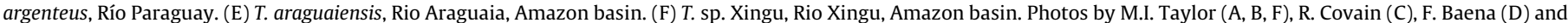
B.F. Melo (E).

reconstruct formal phylogenetic relationships due the limited coverage of their dataset composed by a single mitochondrial locus commonly used for species discrimination (Hebert et al., 2003). As such, neither morphological nor molecular-based phylogenetic hypothesis among species of Tetragonopterus currently exist.

To resolve these apparent conflicts regarding genus-level relationships between Tetragonopterus and other characids, and also to reconstruct the unknown species-level phylogeny for the genus, we undertook a new molecular-based analysis containing all recognized species of Tetragonopterus. We incorporated these species into a large molecular dataset of the Characidae (Oliveira et al., 2011), generated a time-calibrated phylogeny using the available fossil record and provided a well-supported framework for future evolutionary studies within the genus.

\section{Materials and methods}

\subsection{Taxon sampling and morphological comparisons}

Voucher specimens were fixed in $95 \%$ ethanol or $10 \%$ formalin and then transferred to $70 \%$ ethanol for permanent storage. Ingroup taxa included 28 specimens covering a total of seven described species of Tetragonopterus plus three other putative new species and Moenkhausia georgiae (Table 1). Outgroup contains 192 characiform taxa with a species-rich coverage of the Characidae previously generated using the same loci (Oliveira et al., 2011). Comparative morphological analyses were conducted in the following taxa: Charax leticiae: LBP 7600, 1, $59.0 \mathrm{~mm}$ Standard Length (SL); Exodon paradoxus: LBP 8851, 47.1-58.3 mm SL; Gymnocorymbus ternetzi: LBP 8443, 13, 21.2-45.3 mm SL; Moenkhausia georgiae: ANSP 94708, 1 paratype, $57.9 \mathrm{~mm} \mathrm{SL;} M$. xinguensis: MZUSP 36806, 1, $46.8 \mathrm{~mm}$ SL; Poptella compressa:
MCP 25629, 2, 43.6-46.1 mm SL; P. paraguayensis: MZUSP 36715 , 1 cleared and stained (c\&s), $55.9 \mathrm{~mm}$ SL; LIRP 4565, $1 \mathrm{c \& s}$, 54.6 mm SL; Roeboexodon sp.: LBP 16101, 1, 82.8 mm SL; Roeboides bonariensis: LBP 9248, 2, 75.5-82.4 mm SL; Stichonodon insignis: LIRP 5083, 2 c\&s, 35.0-37.5 mm SL; Tetragonopterus anostomus: LBP 7687, 17 paratypes, 34.6-38.9 mm SL; T. araguaiensis: MZUSP 111003, 5 paratypes, $48.4-53.0 \mathrm{~mm} \mathrm{SL;} \mathrm{T.} \mathrm{argenteus:} \mathrm{MZUSP}$ 15570, 2 c\&s, 58.9-67.3 mm SL; T. carvalhoi: LBP 5376, 30 paratypes, 29.7-45.8 mm SL; T. chalceus: MZUSP 29817, 2, 44.9$47.1 \mathrm{~mm} \mathrm{SL}$; . denticulatus: LBP 1585, 6 paratypes (one c\&s), 48.5-61.7 mm SL; T. rarus: LBP 5375, 1, 38.0 mm SL; T. sp. São Francisco: LBP 10294, 21, 70.7-91.3 mm SL; T. sp. Xingu: MZUSP 91950, 60, 52.6-39.1 mm SL; T. sp. Tapajós: LBP 13949, 3, 62.8$65.9 \mathrm{~mm}$ SL. Osteological analysis was conducted on cleared and counterstained specimens following methods of Taylor and Van Dyke (1985) and Weitzman (1974). Museum abbreviatures follow Sabaj Pérez (2013).

\subsection{DNA extraction and sequencing}

Genomic DNA was extracted from tissue muscles using a DNeasy Tissue kit (Qiagen Inc.; www.qiagen.com) according to manufacturer's instructions. We used one round of polymerase chain reaction (PCR) to amplify three mitochondrial loci, the $16 S$, Cytochrome b (Cytb) and Cytochrome oxidase c subunit 1 (Coi). In addition, we obtained sequences of the nuclear myosin heavy chain 6 gene (Myh6), recombination activating gene 1 (Rag1), and recombination activating gene 2 (Rag2) following the nested-PCR procedures obtained in Oliveira et al. (2011). We used $12.5 \mu \mathrm{l}$ as a total volume containing $9.075 \mu \mathrm{l}$ of double-distilled water, $1.25 \mu \mathrm{l} 5 \times$ reaction buffer, $0.375 \mu \mathrm{lgCl}_{2}, 0.25 \mu \mathrm{l} \mathrm{dNTP}$ mix at $8 \mathrm{mM}, 0.25 \mu \mathrm{l}$ of each primer at $10 \mu \mathrm{M}, 0.05 \mu \mathrm{l}$ Platinum Taq 
Table 1

Taxa, vouchers and locality information of the analyzed specimens of Tetragonopterus. Asterisks after species names represent analyzed paratypes.

\begin{tabular}{|c|c|c|c|c|c|c|}
\hline Taxon & Voucher & Specimen & Locality & Geographic coordinates & City, state & Country \\
\hline $\begin{array}{l}\text { Tetragonopterus } \\
\text { anostomus }\end{array}$ & LBP 7687 & 43527 & Rio Araguaia, Amazon basin & $-14.37666667-50.66888889$ & Cocalinho, Mato Grosso & Brazil \\
\hline $\begin{array}{l}\text { Tetragonopterus } \\
\text { anostomus* }\end{array}$ & LBP 7687 & 43528 & Rio Araguaia, Amazon basin & $-14.37666667-50.66888889$ & Cocalinho, Mato Grosso & Brazil \\
\hline $\begin{array}{l}\text { Tetragonopterus } \\
\text { araguaiensis* }\end{array}$ & LBP 4154 & 11693 & Rio Araguaia, Amazon basin & $-15.89311111-52.25025000$ & Aragarças, Goiás & Brazil \\
\hline $\begin{array}{l}\text { Tetragonopterus } \\
\text { araguaiensis* }\end{array}$ & LBP 7756 & 36372 & Rio Araguaia, Amazon basin & $-13.32300000-50.62241667$ & Cocalinho, Mato Grosso & Brazil \\
\hline $\begin{array}{l}\text { Tetragonopterus } \\
\text { argenteus }\end{array}$ & LBP 3059 & 19144 & Río Orinoco, Orinoco basin & $7.63655556-66.31783333$ & $\begin{array}{l}\text { Caicara del Orinoco, } \\
\text { Bolívar }\end{array}$ & Venezuela \\
\hline $\begin{array}{l}\text { Tetragonopterus } \\
\text { argenteus }\end{array}$ & LBP 3758 & 22029 & Rio Negro, Paraguay basin & $-19.57602778-56.24708333$ & $\begin{array}{l}\text { Aquidauana, Mato Grosso } \\
\text { do Sul }\end{array}$ & Brazil \\
\hline $\begin{array}{l}\text { Tetragonopterus } \\
\text { argenteus }\end{array}$ & LBP 5535 & 27201 & Rio Balsas, Parnaíba basin & $-7.54055556-46.03916667$ & Balsas, Maranhão & Brazil \\
\hline $\begin{array}{l}\text { Tetragonopterus } \\
\text { argenteus }\end{array}$ & LBP 12578 & 54261 & Río Marañon, Amazon basin & $-4.13711111-73.52113889$ & Nauta, Loreto & Peru \\
\hline $\begin{array}{l}\text { Tetragonopterus } \\
\text { carvalhoi* }\end{array}$ & LBP 5306 & 26906 & Rio Jari, Amazon basin & $-0.56750000-52.57805556$ & Laranjal do Jari, Amapá & Brazil \\
\hline $\begin{array}{l}\text { Tetragonopterus } \\
\text { carvalhoi* }\end{array}$ & LBP 5306 & 26907 & Rio Jari, Amazon basin & $-0.56750000-52.57805556$ & Laranjal do Jari, Amapá & Brazil \\
\hline Tetragonopterus chalceus & LBP 12581 & 54266 & Río Marañon, Amazon basin & $-4.30377777-73.5211388$ & Nauta, Loreto & Peru \\
\hline Tetragonopterus chalceus & LBP 8773 & 44050 & Rio Araguaia, Amazon basin & $-13.3230000-50.62241667$ & Cocalinho, Mato Grosso & Brazil \\
\hline Tetragonopterus chalceus & LBP 8857 & 44293 & Rio Araguaia, Amazon basin & $-13.37669444-50.66900000$ & Cocalinho, Mato Grosso & Brazil \\
\hline Tetragonopterus chalceus & LBP 13946 & 56694 & Rio Tapajós, Amazon basin & $-4.28041667-59.99058333$ & Itaituba, Pará & Brazil \\
\hline Tetragonopterus chalceus & LBP 16911 & 64564 & Rio Xingu, Amazon basin & $-13.15377778-51,92186111$ & $\begin{array}{l}\text { Ribeirão Cascalheira, } \\
\text { Mato Grosso }\end{array}$ & Brazil \\
\hline $\begin{array}{l}\text { Tetragonopterus } \\
\text { denticulatus }\end{array}$ & LBP 1629 & 11694 & Rio Araguaia, Amazon basin & $-15.89311111-52.25025000$ & Aragarças, Goiás & Brazil \\
\hline $\begin{array}{l}\text { Tetragonopterus } \\
\text { denticulatus }\end{array}$ & LBP 5751 & 28113 & Rio Araguaia, Amazon basin & $-15.89208333-52.25055556$ & Aragarças, Goiás & Brazil \\
\hline Tetragonopterus rarus & LBP 5375 & 27017 & Rio Jari, Amazon basin & $-0.56416667-52.57916667$ & Laranjal do Jari, Amapá & Brazil \\
\hline Tetragonopterus rarus & $\begin{array}{l}\text { MHNG } \\
2718.028\end{array}$ & $\begin{array}{l}\text { SU08-640 (172- } \\
21)\end{array}$ & $\begin{array}{l}\text { Paloemeu Rivier, Marowijne } \\
\text { basin }\end{array}$ & $3.17833-55.4192$ & Sipaliwini & Suriname \\
\hline Tetragonopterus rarus & $\begin{array}{l}\text { MHNG } \\
2735.090\end{array}$ & $\begin{array}{l}\text { SUGF12-362 } \\
(172-27)\end{array}$ & $\begin{array}{l}\text { Kabalebo Rivier, Corantijn } \\
\text { basin }\end{array}$ & $4.45058-57.1631$ & Sipaliwini & Suriname \\
\hline $\begin{array}{l}\text { Tetragonopterus sp. São } \\
\text { Francisco }\end{array}$ & LBP 8268 & 37556 & Rio São Francisco & $-15.32338888-43.66458333$ & Jaíba, Minas Gerais & Brazil \\
\hline $\begin{array}{l}\text { Tetragonopterus sp. São } \\
\text { Francisco }\end{array}$ & LBP 10394 & 48897 & Rio São Francisco & $-17.32566667-44.76694444$ & Buritizeiro, Minas Gerais & Brazil \\
\hline $\begin{array}{l}\text { Tetragonopterus sp. } \\
\text { Tapajós }\end{array}$ & LBP 13949 & 56698 & Rio Tapajós, Amazon basin & $-4.45819444-56.26750000$ & Itaituba, Pará & Brazil \\
\hline $\begin{array}{l}\text { Tetragonopterus sp. } \\
\text { Tapajós }\end{array}$ & LBP 13949 & 56699 & Rio Tapajós, Amazon basin & $-4.45819444-56.26750000$ & Itaituba, Pará & Brazil \\
\hline Tetragonopterus sp. Xingu & LBP 15711 & 64561 & Rio Xingu, Amazon basin & $-13.15377778-51.92186111$ & $\begin{array}{l}\text { Ribeirão Cascalheira, } \\
\text { Mato Grosso }\end{array}$ & Brazil \\
\hline Tetragonopterus sp. Xingu & LBP 15711 & 64563 & Rio Xingu, Amazon basin & $-13.15377778-51.92186111$ & $\begin{array}{l}\text { Ribeirão Cascalheira, } \\
\text { Mato Grosso }\end{array}$ & Brazil \\
\hline Moenkhausia georgiae & $\begin{array}{l}\text { MHNG } \\
2716.097\end{array}$ & $\begin{array}{l}\text { SU08-848 (172- } \\
22)\end{array}$ & $\begin{array}{l}\text { Tapanahony Rivier, } \\
\text { Marowijne basin }\end{array}$ & $3.366-55.4321$ & Sipaliwini & Suriname \\
\hline Moenkhausia georgiae & $\begin{array}{l}\text { MHNG } \\
2716.097\end{array}$ & $\begin{array}{l}\text { SU08-849 (172- } \\
23)\end{array}$ & $\begin{array}{l}\text { Tapanahony Rivier, } \\
\text { Marowijne basin }\end{array}$ & $3.366-55.4321$ & Sipaliwini & Suriname \\
\hline
\end{tabular}

DNA polymerase enzyme (Invitrogen; www.invitrogen.com) and $1.0 \mu$ l genomic DNA (10-50 ng). Primers were obtained from the literature: 16s (Palumbi, 1996); Cytb, Rag1 and Rag2, 1st PCR (Oliveira et al., 2011); Coi (Melo et al., 2011); Myh6 (Li et al., 2007); Rag2, 2nd PCR (Lovejoy and Collette, 2001). The PCR consisted of an initial denaturation ( $4 \mathrm{~min}$ at $95^{\circ} \mathrm{C}$ ) followed by $28-30$ cycles of chain denaturation $\left(30 \mathrm{~s}\right.$ at $95^{\circ} \mathrm{C}$ ), primer hybridization $\left(30-60 \mathrm{~s}\right.$ at $48-54^{\circ} \mathrm{C}$ ), and nucleotide extension $\left(30-60 \mathrm{~s}\right.$ at $\left.72{ }^{\circ} \mathrm{C}\right)$. After visualization of the fragments using $1 \%$ agarose gel, we performed the sequencing reaction using dye terminators (BigDye ${ }^{\mathrm{TM}}$ Terminator v 3.1 Cycle Sequencing Ready Reaction Kit, Applied Biosystems; www.appliedbiosystems.com) purified again through ethanol precipitation. Samples were then loaded onto an automatic sequencer ABI 3130-Genetic Analyzer (Applied Biosystems) at the Universidade Estadual Paulista, Botucatu, São Paulo, Brazil.

\subsection{Alignment and phylogenetic analyses}

We assembled and edited consensus sequences in Geneious 7.1.7 (www.geneious.com; Kearse et al., 2012) applying IUPAC ambiguity codes where we detected uncertainty of nucleotide identity. We then aligned the consensus sequences of each gene using Muscle algorithm (Edgar, 2004) and inspected alignments by eye for major misalignments and concatenated these into a reduced Characidae matrix containing five loci (Oliveira et al., 2011). In order to reduce computation time and to resolve internal nodes, we used a reduced dataset (six loci) containing only species of Tetragonopterus and Moenkhausia georgiae, along with Exodon and Roeboexodon, Characinae, Iguanodectidae, Acestrorhynchidae and Triportheidae. To evaluate the occurrence of substitution saturation, we estimated the index of substitution saturation in asymmetrical (Iss.cAsym) and symmetrical (Iss.cSym) topologies using 
Dambe 5.3.38 (Xia, 2013). Maximum likelihood (ML) trees for each locus were generated in order to test for incongruence between different loci and identify potentially contaminated sequences. A set of six reasonable partitioning schemes, ranging from 1 to 13 partitions, was tested following the procedures outlined by $\mathrm{Li}$ et al. (2008) using the Akaike information criterion (AIC) and Bayesian information criterion (BIC) (results not shown). The best-fit model of nucleotide substitution was searched in Mega 5.04 (Tamura et al., 2011) under default parameters using the AIC (see Posada and Buckley, 2004 for justification).

A maximum likelihood (ML) analysis of the partitioned data (13 partitions) was performed in RAxML HPC2 on XSEDE (Stamatakis, 2006) implemented on CIPRES (Miller et al., 2010). We used random starting trees with GTR+G model (Stamatakis et al., 2008), and keep other parameters at default values. All ML analyses were conducted following the 13 partitions scheme as suggested by the AIC and BIC. Topological robustness was investigated using 1000 non-parametric bootstrap replicates.

\subsection{Divergence time and node-age estimations}

The estimation of divergence time in the ML phylogeny was carried out using Beast 1.8.0 (Drummond et al., 2012) on a reduced dataset that included the subfamily Tetragonopterinae along with members of Characinae, Exodon/Roeboexodon, and representatives of the families Acestrorhynchidae, Iguanodectidae and Triportheidae. To calibrate our molecular tree we followed the guideline proposed by Parham et al. (2012). †Lignobrycon ligniticus (Woodward, 1898) (type specimen: BMNH P9012) is sister to L. myersi and this clade is sister to Triportheus (Malabarba, 1998) within the Triportheidae. Both L. myersi and Triportheus were included in our dataset.

$\nmid$ Lignobrycon ligniticus was described based on complete specimens collected in the Tremembé Formation, Taubaté Basin, São
Paulo, Brazil. A geological study (Riccomini et al., 1991) dated the formation for the Oligocene, as well as suggested by paleontological studies with mammals (Soria and Alvarenga, 1989) and pollens (Lima et al., 1985). Following the International Commission on Stratigraphy (www.stratigraphy.org), the Oligocene extended from 33.9 to 23.03 million of years ago (Ma). These dates were implemented in BEAST with a log-normal prior offset with a mean and standard deviation of $28.5 \pm 5.5$. We used a birth-death model for the speciation likelihood and a random starting tree. The analysis was performed with 10 million generations with sampled trees every 1000th generation. Stationarity and sufficient mixing of parameters $(E S S>200)$ were checked using Tracer 1.5 (Rambaut et al., 2014). A final tree was built using FigTree v.1.4.2.

\section{Results}

The concatenated matrix included 4663 bp spanning 220 species of the Characidae (sensu Oliveira et al., 2011) and other six families of the Characiformes. The reduced dataset contains $5047 \mathrm{bp}$ of 48 species, including species of Tetragonopterus and Moenkhausia georgiae, along with Exodon and Roeboexodon, Characinae, Iguanodectidae, Acestrorhynchidae and Triportheidae. Content information and characteristics of each molecular data partition are represented in Table 2. All data were further tested to investigate the occurrence of substitution saturation and the results did not show any significant saturation. All generated sequences are deposited on GenBank with accession numbers: 16S KT880470-KT880492, Cytb KT895104-KT895123, Myh6 KT895124-KT895143, Rag1 KT895144-KT895163, Rag2 KT895164-185, and Coi KT895186-KT895198.

Our molecular phylogeny (Fig. 2) strongly supports a monophyletic Tetragonopterinae that contains only species of Tetragonopterus plus Moenkhausia georgiae as sister to Exodon and

Table 2

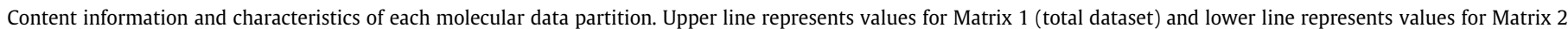
(Tetragonopterinae and allied species).

\begin{tabular}{|c|c|c|c|c|c|c|c|}
\hline & $16 S$ & CytB & Myh6 & Rag1 & Rag2 & Coi & Total \\
\hline Number of sequences & $\begin{array}{l}220(100 \%) \\
44(91.7 \%)\end{array}$ & $\begin{array}{l}202(91.8 \%) \\
40(83.3 \%)\end{array}$ & $\begin{array}{l}203(92.2 \%) \\
37(77.1 \%)\end{array}$ & $\begin{array}{l}202(91.8 \%) \\
37(77.1 \%)\end{array}$ & $\begin{array}{l}200(90.9 \%) \\
41(85.4 \%)\end{array}$ & - 39 (81.3\%) & $\begin{array}{l}220 \\
48\end{array}$ \\
\hline Base pairs after alignment & $\begin{array}{l}620 \\
606\end{array}$ & $\begin{array}{l}992 \\
992\end{array}$ & $\begin{array}{l}755 \\
741\end{array}$ & $\begin{array}{l}1265 \\
1028\end{array}$ & $\begin{array}{l}1031 \\
1023\end{array}$ & $\begin{array}{l}- \\
657\end{array}$ & $\begin{array}{l}4663 \\
5047\end{array}$ \\
\hline Number of variable sites & $\begin{array}{l}249 \\
220\end{array}$ & $\begin{array}{l}652 \\
492\end{array}$ & $\begin{array}{l}352 \\
194\end{array}$ & $\begin{array}{l}760 \\
347\end{array}$ & $\begin{array}{l}918 \\
367\end{array}$ & $\begin{array}{l}- \\
276\end{array}$ & $\begin{array}{l}3031 \\
1896\end{array}$ \\
\hline Number of informative characters under parsimony & $\begin{array}{l}294 \\
172\end{array}$ & $\begin{array}{l}542 \\
428\end{array}$ & $\begin{array}{l}295 \\
139\end{array}$ & $\begin{array}{l}596 \\
216\end{array}$ & $\begin{array}{l}539 \\
243\end{array}$ & $\begin{array}{l}- \\
241\end{array}$ & $\begin{array}{l}2266 \\
1439\end{array}$ \\
\hline$\%$ informative characters under parsimony & $\begin{array}{l}47.4 \\
28.4\end{array}$ & $\begin{array}{l}54.6 \\
43.1\end{array}$ & $\begin{array}{l}39.1 \\
18.7\end{array}$ & $\begin{array}{l}47.1 \\
21.0\end{array}$ & $\begin{array}{l}52.3 \\
23.8\end{array}$ & $\begin{array}{l}0 \\
36.7\end{array}$ & $\begin{array}{l}48.6 \\
28.5\end{array}$ \\
\hline$\Pi_{\mathrm{T}}$ & $\begin{array}{l}0.232 \\
0.231\end{array}$ & $\begin{array}{l}0.304 \\
0.299\end{array}$ & $\begin{array}{l}0.245 \\
0.248\end{array}$ & $\begin{array}{l}0.224 \\
0.222\end{array}$ & $\begin{array}{l}0.230 \\
0.234\end{array}$ & $\begin{array}{l}- \\
0.311\end{array}$ & $\begin{array}{l}0.246 \\
0.255\end{array}$ \\
\hline$\Pi_{\mathrm{C}}$ & $\begin{array}{l}0.231 \\
0.227\end{array}$ & $\begin{array}{l}0.283 \\
0.290\end{array}$ & $\begin{array}{l}0.215 \\
0.213\end{array}$ & $\begin{array}{l}0.241 \\
0.227\end{array}$ & $\begin{array}{l}0.254 \\
0.250\end{array}$ & $\overline{0}-261$ & $\begin{array}{l}0.247 \\
0.246\end{array}$ \\
\hline$\Pi_{\mathrm{A}}$ & $\begin{array}{l}0.315 \\
0.318\end{array}$ & $\begin{array}{l}0.266 \\
0.268\end{array}$ & $\begin{array}{l}0.305 \\
0.306\end{array}$ & $\begin{array}{l}0.250 \\
0.252\end{array}$ & $\begin{array}{l}0.243 \\
0.242\end{array}$ & 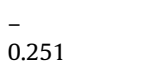 & $\begin{array}{l}0.270 \\
0.269\end{array}$ \\
\hline$\Pi_{\mathrm{G}}$ & $\begin{array}{l}0.222 \\
0.224\end{array}$ & $\begin{array}{l}0.246 \\
0.143\end{array}$ & $\begin{array}{l}0.235 \\
0.234\end{array}$ & $\begin{array}{l}0.285 \\
0.299\end{array}$ & $\begin{array}{l}0.274 \\
0.274\end{array}$ & $\overline{0}-178$ & $\begin{array}{l}0.237 \\
0.230\end{array}$ \\
\hline Overall mean genetic distance ( $p$-distance) & $\begin{array}{l}0.119 \pm 0.007 \\
0.088 \pm 0.006\end{array}$ & $\begin{array}{l}0.197 \pm 0.007 \\
0.185 \pm 0.008\end{array}$ & $\begin{array}{l}0.066 \pm 0.004 \\
0.050 \pm 0.004\end{array}$ & $\begin{array}{l}0.089 \pm 0.004 \\
0.061 \pm 0.004\end{array}$ & $\begin{array}{l}0.088 \pm 0.004 \\
0.062 \pm 0.004\end{array}$ & $\overline{0}-161 \pm 0.010$ & $\begin{array}{l}0.104 \pm 0.002 \\
0.112 \pm 0.003\end{array}$ \\
\hline Nucleotide substitution model & $\begin{array}{l}\text { GTR }+\mathrm{I}+\Gamma \\
\mathrm{GTR}+\mathrm{I}+\Gamma\end{array}$ & $\begin{array}{l}\mathrm{GTR}+\mathrm{I}+\Gamma \\
\mathrm{HKY}+\mathrm{I}+\Gamma\end{array}$ & $\begin{array}{l}\mathrm{T} 92+\mathrm{I}+\Gamma \\
\mathrm{T} 92+\Gamma\end{array}$ & $\begin{array}{l}\mathrm{K} 2 \mathrm{P}+\mathrm{I}+\Gamma \\
\mathrm{K} 2 \mathrm{P}+\Gamma\end{array}$ & $\begin{array}{l}\mathrm{K} 2 \mathrm{P}+\Gamma \\
\mathrm{K} 2 \mathrm{P}+\Gamma\end{array}$ & $\overline{\mathrm{GTR}+\mathrm{I}+\Gamma}$ & $\begin{array}{l}\text { GTR }+\mathrm{I}+\Gamma \\
\mathrm{GTR}+\mathrm{I}+\Gamma\end{array}$ \\
\hline$\alpha$ (shape) parameter of $\Gamma$ distribution & $\begin{array}{l}0.63 \\
0.41\end{array}$ & $\begin{array}{l}0.63 \\
0.91\end{array}$ & $\begin{array}{l}1.03 \\
-\end{array}$ & $\begin{array}{l}0.77 \\
0.33\end{array}$ & $\begin{array}{l}0.43 \\
0.39\end{array}$ & $\begin{array}{l}- \\
0.93\end{array}$ & $\begin{array}{l}0.57 \\
0.46\end{array}$ \\
\hline Proportion of invariants (I) sites & $\begin{array}{l}0.35 \\
0.39\end{array}$ & $\begin{array}{l}0.35 \\
0.44\end{array}$ & $\begin{array}{l}0.46 \\
-\end{array}$ & $\begin{array}{l}0.30 \\
-\end{array}$ & $\begin{array}{l}- \\
-\end{array}$ & $\begin{array}{l}- \\
0.53\end{array}$ & $\begin{array}{l}0.40 \\
0.39\end{array}$ \\
\hline
\end{tabular}




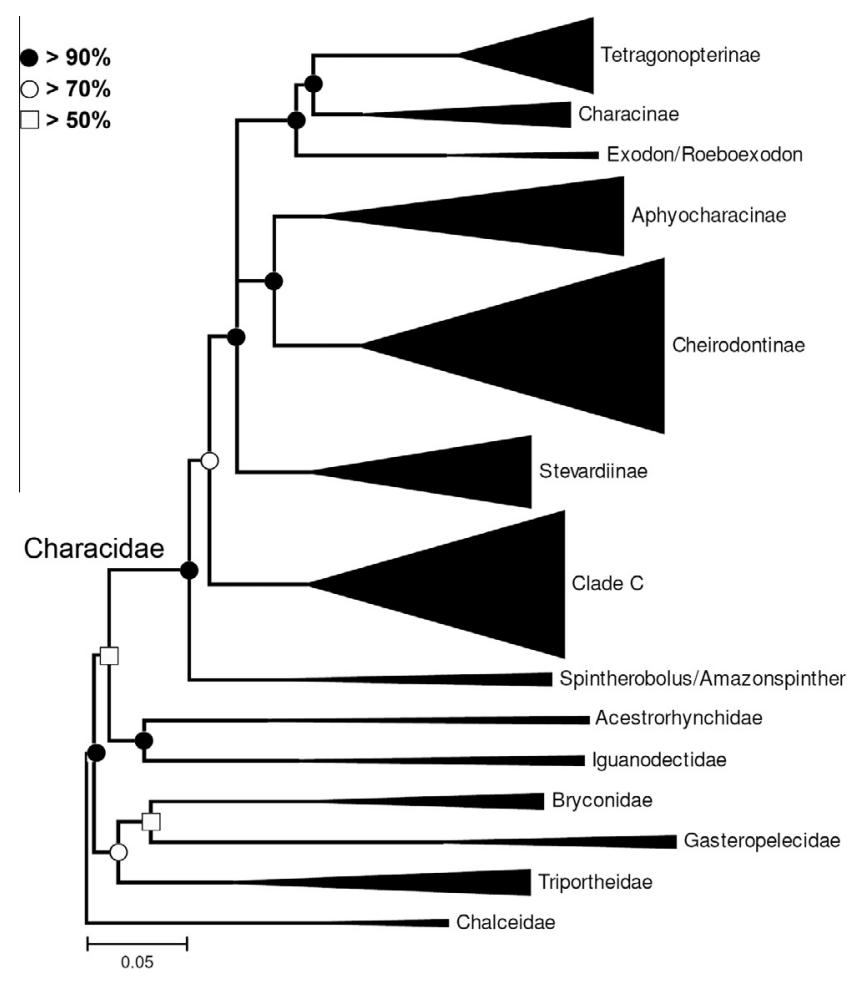

Fig. 2. Summary of the relationships among major lineages of Characidae and related families obtained by a maximum likelihood analysis of the concatenated dataset.

Roeboexodon. This clade appeared sister to the subfamily Characinae. Evidence for generic allocation of Moenkhausia georgiae within Tetragonopterus are being provided by Silva et al. (in preparation). The best-supported time-calibrated phylogeny (Fig. 3) estimated a Late Oligocene crown age for the clade composed by Characinae, Exodon/Roeboexodon and Tetragonopterinae (25 Ma; 95\% highest posterior density, HPD, 15-36 Ma) and a Late Oligocene-Early Miocene crown age for Tetragonopterus and the clade composed by Exodon and Roeboexodon (23 Ma, 14-33 Ma HPD).

The first two internal ramifications within the Tetragonopterinae occurred contemporaneously during the middle Miocene (Fig. 3). First, Moenkhausia georgiae split from the remaining Tetragonopterus approximately $18 \mathrm{Ma}$ (10-26 Ma HPD), and T. rarus split from the remaining congeners at around $15 \mathrm{Ma}$ (9-22 Ma HPD). The Miocene was also the time for diversification of several subclades within the Tetragonopterus as, for example, the split between the clade of T. anostomus, T. denticulatus, and Tetragonopterus sp. Xingu and the remaining Tetragonopterus that occurred $\sim 13 \mathrm{Ma}$ (7-18 Ma HPD). Radiations within the clade ( $T$. denticulatus (T. anostomus $+T$. sp. Xingu)) began at approximately $7 \mathrm{Ma}$ (3.5-10.5 Ma HPD). Late Miocene was the time that Tetragonopterus argenteus split from the remaining Tetragonopterus at $\sim 10 \mathrm{Ma}$ (5.7-14.9 Ma HPD), and T. chalceus separated from the less inclusive clade at 8.3 Ma (4.6-12 Ma HPD). We also estimated that the clade (( $T$. carvalhoi $+T$. sp. São Francisco) ( $T$. araguaiensis $+T$. sp. Tapajós)) split from one another $\sim 7$ Ma (4-10 Ma HPD) and those internal radiations dated to Late Miocene-Early Pliocene (5 Ma, 2-9 Ma HPD).

\section{Discussion}

\subsection{Phylogenetic relationships within the Tetragonopterinae}

Tetragonopterinae, known as American tetras, was recognized for a long time as a large fish assemblage containing "the most successful characoids" of the neotropics (Géry, 1977). However, the lack of synapomorphies supporting such a large clade led Reis (2003) to restrict the subfamily to Tetragonopterus and the remaining 87 genera were allocated as incertae sedis in Characidae (Lima et al., 2003). Tetragonopterinae was subsequently reexpanded to include Tetragonopterus and 18 more characid genera in a morphological analysis of the Characidae (Mirande, 2010). The proposed synapomorphy that supports the subfamily is the presence of two uroneurals, a character state that occurs homoplasticly across the Characidae (Mirande, 2010). Subsequent molecular phylogenies (Javonillo et al., 2010; Oliveira et al., 2011) and a morphological phylogeny of the Characinae (Mattox and Toledo-Piza, 2012) did not corroborate such morphological arrangement. Mirande (2010) also hypothesized Tetragonopterus as the sister genus of the clade containing Gymnocorymbus, Stichonodon, and Stethaprioninae (Poptella and Stethaprion) supported by four nonexclusive synapomorphies. Again, this placement was not corroborated by molecular studies (e.g. Oliveira et al., 2011).

Molecular phylogenies alternatively concord in recognizing the analyzed species of Tetragonopterus as sister to Characinae (Javonillo et al., 2010) including Microschemobrycon, and with Exodon and Roeboexodon (Oliveira et al., 2011). Interestingly, Mattox and Toledo-Piza (2012) used morphological data to redefine Characinae with the resolution (Phenacogasterini (Characini + Cynopotamini) and found Tetragonopterus as its closest sister group. Additional molecular studies focusing on the Aphyocharacinae, Cheirodontinae, Stevardiinae and Gymnocorymbus added more taxa and corroborated Tetragonopterus closer to Characinae (Tagliacollo et al., 2012; Mariguela et al., 2013; Thomaz et al., 2015; Benine et al., 2015). Here, we found a well-supported monophyletic clade of Tetragonopterinae (including all species of Tetragonopterus plus Moenkhausia georgiae) sister to Exodon plus Roeboexodon and this clade sister to Characinae (including Microschemobrycon) (Figs. 2 and 3), which agrees with both molecular and morphological hypotheses (Oliveira et al., 2011; Mattox and Toledo-Piza, 2012) with the sole exception of Mirande (2010).

Prior taxonomic studies using both morphology and DNA barcoding revealed the presence of three mitochondrial lineages within Tetragonopterus (Melo et al., 2011; Silva et al., 2013). Our multilocus analyses with all recognized species of Tetragonopterus found a higher number of monophyletic, strongly supported clades. The first clade to diversify is Moenkhausia georgiae from the Guianas, a species formally assigned as a member of Moenkhausia (Géry, 1965). Generic allocation of M. georgiae is perhaps unsurprising due the overall non-homologous similarities with some deep-bodied species of Moenkhausia (e.g. M. chrysargyrea, M. grandisquamis). However, a taxonomic review of Tetragonopterus (Silva et al., in preparation) provides evidence for a new allocation of the species within Tetragonopterus. The sister clade to $M$. georgiae is T. rarus (a species from the Guianas and Rio Jari of the lower Amazon basin) as the sister group of the remaining species. Silva et al. (2013) found that T. rarus represents a distinct mitochondrial lineage within Tetragonopterus, a result consistent with our multilocus phylogeny.

The sister clade to Tetragonopterus rarus contains nine species ( $T$. anostomus, T. araguaiensis, T. argenteus, T. carvalhoi, T. chalceus, T. denticulatus, T. sp. São Francisco, T. sp. Tapajós, and T. sp. Xingu). These share the presence of a pronounced downward curvature of the anterior portion of the pored scales, a feature not observed neither in Moenkhausia georgiae nor T. rarus. Such novelty is likely due the modification in the entire structure and disposition of the horizontal scale rows along the body carrying out the laterosensory canal in the same way down. Such derived condition of the downward curvature of the lateral line may be interpreted, in light of our phylogeny, as a putative synapomorphy for this major, less inclusive clade of Tetragonopterus. Further comparative studies focusing 


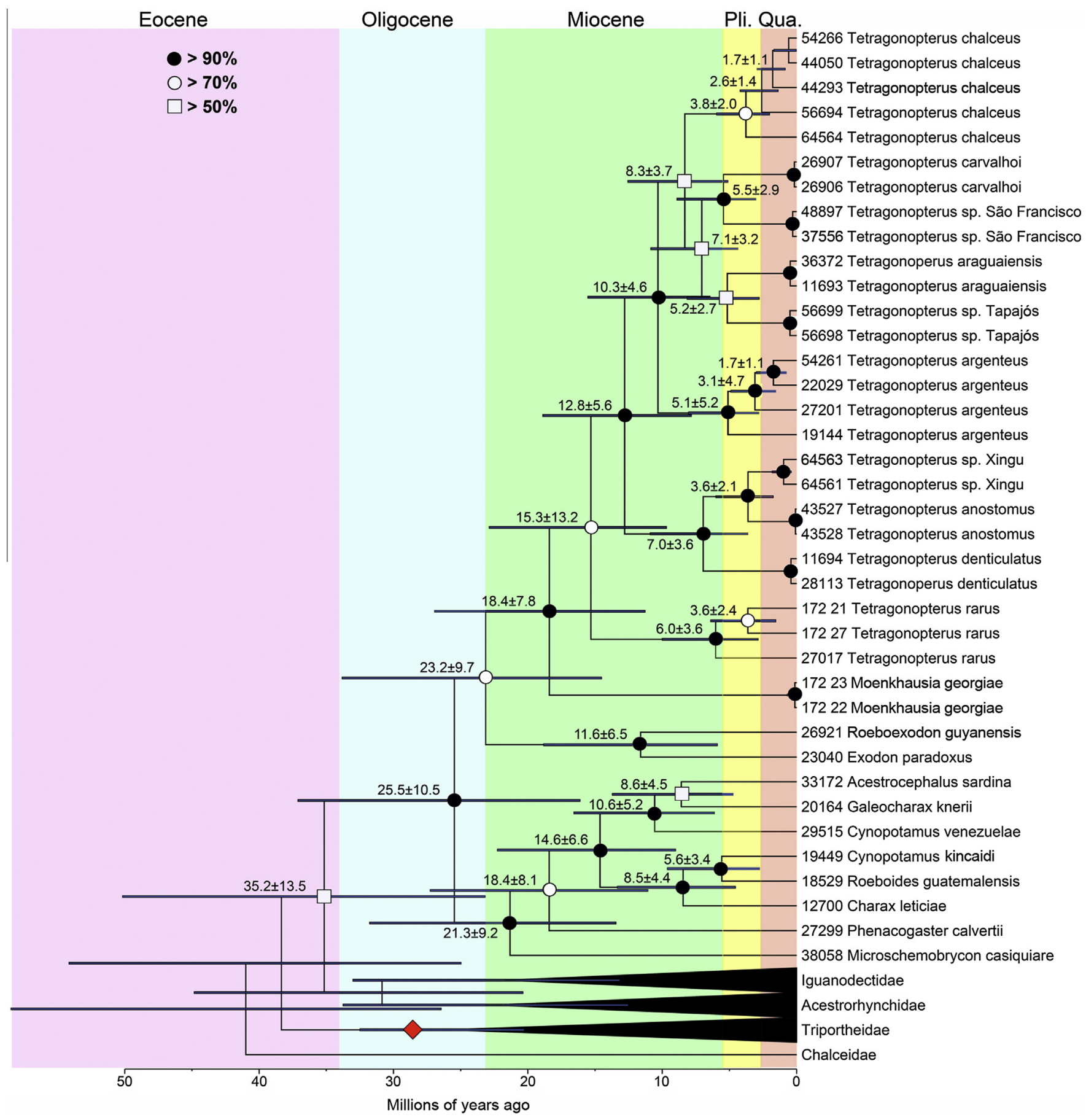

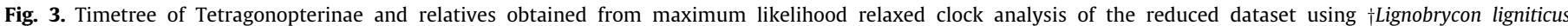

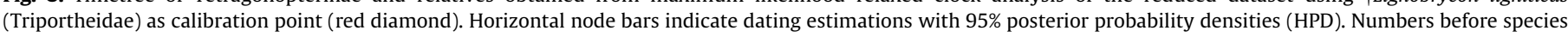

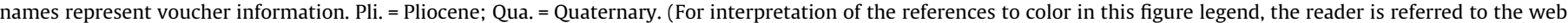
version of this article.)

on how these modifications occur ontogenetically across the Tetragonopterinae may address important information on the character evolution.

Tetragonopterus denticulatus is sister to T. anostomus and T. sp. Xingu, all three species from the Brazilian Shield in the Araguaia and Xingu river systems of the eastern Amazon basin. These three species share the presence of numerous (never less than five) and minuscule teeth in the lower jaw that may represent a putative synapomorphy to be confirmed in a more comprehensive morphological analysis. Internal diversification within this three-species clade involved, among others, modifications in dentition, mouth morphology and pigmentation (Silva et al., in preparation). As example, the presence of only one conspicuous humeral mark unites the species pair T. anostomus and $T$. sp. Xingu.

Tetragonopterus argenteus is well supported as a monophyletic species and appeared sister to the remaining species. Melo et al. (2011) proposed T. argenteus as a species complex with multiple, biogeographically structured mitochondrial lineages. We accordingly found that subsequent multiple radiations occurred during the Plio-Pleistocene $(\sim 5-2 \mathrm{Ma})$ within the $T$. argenteus. The 
specimen from the Orinoco basin in Venezuela, for example, split from the other three specimens at around $5 \mathrm{Ma}$ and subsequent radiations occurring at $\sim 3-2$ Ma that split populations from the Rio Parnaíba of the Northeastern Brazil and then the sister pair composed by specimens from the Río Marañon and Rio Paraguay. Such strong evidence provides foundation to corroborate Melo et al.'s (2011) hypothesis of the presence of sibling species within the present concept of $T$. argenteus. The presence of more than 10 scales in the predorsal line, from the tip of the occipital spine to the origin of dorsal fin, may represent a putative synapomorphy and, thus, a definition for the herein called T. argenteus species complex.

Our phylogeny supports monophyly for the five analyzed specimens of Tetragonopterus chalceus, the most widespread species of the genus together with $T$. argenteus. The taxonomic revision shows that populations from distinct drainages are morphologically undistinguishable from each other and that only one name should be currently used to address this form, the $T$. chalceus (Silva et al., in preparation). The taxonomy of both $T$. argenteus and $T$. chalceus would better benefit from further investigation through alternative techniques (e.g. geometric morphometrics) and/or population genetics with extensive sampling to better determine the limits of this putative species. Indeed, adequate sample sizes relative to South American fishes are still a bottleneck to such comparative studies and, as a consequence, a long way likely exists to have such hypothesis tested.

Tetragonopterus carvalhoi is highly supported as sister to $T$. sp. São Francisco and T. araguaiensis sister to $T$. sp. Tapajós with moderate support. The modified lozenge-shaped mark on the caudal peduncle that diagnoses T. carvalhoi (Melo et al., 2011) is unique among Tetragonopterus species and may represent an autapomorphic condition to be further tested in more inclusive morphological studies. Specimens of Tetragonopterus sp. São Francisco share the presence of a lower number of olfactory lamellae (less than 17), a unique condition in Tetragonopterus (Silva et al., in preparation). Our results revealed that $T$. araguaiensis is not related to T. anostomus, as one could expect, in which both share the presence of 18-20 gill rakers on the lower limb of the branchial arches (Silva et al., 2013). Such feature is then interpreted as homoplastic and may be linked to the same feeding strategies adopted by these sympatric species inhabiting the Rio Araguaia of the Amazon basin.

\subsection{Timing of Tetragonopterinae evolution and historical biogeography}

Our relaxed molecular clock tree based on the available fossil record (Fig. 3) reveals a Late Oligocene/Early Miocene origin for diversification within Tetragonopterus ( $18 \mathrm{Ma})$. Hydrographic dynamic across the Amazon basin during the Miocene (24-6 Ma) is well documented (Hoorn et al., 2010; Wesselingh and Hoorn, 2011 and references therein). Most notably, the Pebas system was predominantly dominated by lakes and lowland areas (Hoorn, 1993), which served as home for most Amazonian fishes that were able to move freely over almost the entire western Amazon (Wesselingh and Hoorn, 2011). Additionally, the Purus arch divided westerly and easterly drainages until the Late Miocene (Figueiredo et al., 2009) with cratonic rivers of the Guianese and Brazilian shields draining eastward (Harris and Mix, 2002; Figueiredo et al., 2009). This could potentially suggest that these major isolations promoted the first two contemporaneously diversifications within Tetragonopterus splitting Moenkhausia georgiae and then T. rarus from the Guiana Shield to the clade with remaining species during the Early-Middle Miocene.

Our dated phylogeny shows that subsequent cladogenetic events occurred mostly during the Middle and Late Miocene at 13-6 Ma (Fig. 3). This time coincides with the establishment of an initial transcontinental drainage system with the formation of the main Amazon river channel (Figueiredo et al., 2009) through the uplift of mountain chains in the Central and Northern Andes ( $\sim 12 \mathrm{Ma}$ ) that may have promoted events of allopatric speciation and extinction (Hoorn et al., 2010). The La Venta formation in the present Magdalena Valley of Colombia, for example, contains deposits from the Middle Miocene (13.5-11.5 Ma) with numerous fossils of Neotropical fishes with living relatives (Lundberg et al., 1998). The combination of strong geological activity during that time may have influenced cladogenetic events within Tetragonopterus. More recently, species diversification within Tetragonopterus occurred during the Pliocene ( $\sim 5-2.5 \mathrm{Ma})$ when climate oscillation influenced sea level fluctuations and transgression across South America (Hubert and Renno, 2006; Hubert et al., 2007), despite this relatively recent marine incursion hypothesis remains in debate (Bloom and Lovejoy, 2011). Sedimentological and palynological data was used to propose two major marine incursions, first occurring 20-17 Ma and the second 12-10 Ma (Hoorn, 1993; Hoorn et al., 2010). Within this context, we suggest that Miocene transgressions played an important role on the colonization with subsequent species diversification in Tetragonopterus dwelling in the Brazilian Shield of the Tocantins-Araguaia, São Francisco, Tapajós and Xingu basins through ancient wetlands of the Paranense Sea (Lundberg et al., 1998; Lima and Ribeiro, 2011).

Another interesting result is the timing of diversification within the Tetragonopterus argenteus. It is widely distributed throughout most of the South American drainages, being the single Tetragonopterus species occurring in the Paraná-Paraguay system. We found that the specimen from the Río Paraguay split from that one from the Río Marañon in the Peruvian Amazon during the Quaternary at approximately $1.7 \mathrm{Ma}$ (Fig. 3). Interestingly, phylogeographic studies with Neotropical fishes have revealed similar results. For example, Sivasundar et al. (2001) found that Prochilodus nigricans from the Amazon basin split from $P$. lineatus from the Paraguay basin at around 4-2 Ma. Similarly, Hubert et al. (2007) used a molecular clock analysis of mtDNA and estimated a separation between specimens of Pygocentrus nattereri from the upper Amazon and upper Paraná-Paraguay basins at around 1.8 Ma. These coincident diversification can be explained by the origin of the Pantanal Wetland by tectonic reactivations of Precambrian faults at around $2.5 \mathrm{Ma}$ (Soares et al., 1998; Assine, 2004), as hypothesized for Neotropical rheophilic fishes (Ribeiro et al., 2013). Such event likely promoted the subsequent colonization of the lineage of $T$. argenteus living nowadays in the Paraguay and lower Paraná basins.

Overall, our molecular dated phylogeny depicts the interspecific relationships within Tetragonopterus that can permit future research on the evolutionary processes modulating species diversification within the genus. Our results also corroborate the molecular hypothesis of the composition of Tetragonopterinae exclusively by Tetragonopterus and its placement as close related to Characinae and relatives. Further ecological aspects should be addressed to understand the variety of morphological features present in distinct and diverse monophyletic lineages of Tetragonopterus presented herein.

\section{Acknowledgments}

We thank R. Covain (MHNG) for sequences of Moenkhausia georgiae and Tetragonopterus rarus from Suriname and M. Taylor for life coloration photos. We are grateful to G. Ortí, J.M. Mirande and an anonymous reviewer for the careful revision of this manuscript. Authors were funded by CNPq - Brazil PDJ 40258/2014-7 and FAPESP - Brazil proc. 2011/08374-1 (BFM), proc. 2006/00545-3 (RCB), proc. 2012/01622-2 (GSCS), proc. 2011/17746-0 (GSA) and proc. 2010/17009-2 (CO). This study was also part of the FAPESP Thematic Project "Phylogenetic relationships in the Characidae 
(Ostariophysi: Characiformes)" (FAPESP grant 04/09219-6) and benefits from the FAPESP Thematic Project "South American Characiformes Inventory” (FAPESP grant 11/50282-7).

\section{References}

Araujo, L.B.S., Lucinda, P.H.F., 2014. A new species of the genus Tetragonopterus Cuvier, 1816 (Ostariophysi: Characiformes: Characidae) from the rio Tocantins drainage, Brazil. Neotrop. Ichthyol. 12, 309-315. http://dx.doi.org/10.1590/ 1982-0224-20130173.

Assine, M.L., 2004. A bacia sedimentar do Pantanal Mato-Grossense. In: MantessoNeto, V., Bartorelli, A., Carneiro, C.D.R., Brito-Neves, B.B. (Eds.), Geologia Do Continente Sul-Americano: Evolução Da Obra de Fernando Flávio Marques de Almeida. Editora Beca, São Paulo, pp. 61-74.

Benine, R.C., Melo, B.F., Castro, R.M.C., Oliveira, C., 2015. Taxonomic revision and molecular phylogeny of Gymnocorymbus Eigenmann, 1908 (Teleostei, Characiformes, Characidae). Zootaxa 3956, 1-28.

Benine, R.C., Pelição, G.Z., Vari, R.P., 2004. Tetragonopterus lemniscatus (Characiformes: Characidae), a new species from the Corantijn River basin in Suriname. Proc. Biol. Soc. Wash. 117, 339-345.

Bloom, D.D., Lovejoy, N.R., 2011. The biogeography of marine incursions in South America. In: Albert, J.S., Reis, R.E. (Eds.), Historical Biogeography of Neotropical Freshwater Fishes. University of California Press, Berkeley and Los Angeles, pp. $137-144$.

Drummond, A.J., Suchard, M.A., Xie, D., Rambaut, A., 2012. Bayesian phylogenetics with BEAUti and the BEAST 1.7. Mol. Biol. Evol. 29, 1969-1973. http://dx.doi. org/10.1093/molbev/mss075.

Edgar, R., 2004. Muscle: a multiple sequence alignment method with reduced time and space complexity. BMC Bioinformatics 5, 1-19.

Eigenmann, C.H., 1903. New genera of South American fresh-water fishes, and new names for old genera. Smiths. Miscel. Col. 45, 144-148.

Eigenmann, C.H., 1908. Preliminary descriptions of new genera and species of tetragonopterid characins. Bull. Mus. Comp. Zool. 52, 91-106.

Eigenmann, C.H., 1917. The American Characidae [Part 1]. Mem. Mus. Comp. Zool. 43, $1-102$.

Figueiredo, J., Hoorn, C., van der Ven, P., Soares, E., 2009. Late Miocene onset of the Amazon River and the Amazon deep-sea fan: evidence from the Foz do Amazonas Basin. Geology 37, 619-622. http://dx.doi.org/10.1130/G25567A.1.

Géry, J., 1965. Notes on characoid fishes collected in Surinam by Mr. H.P. Pijpers, with descriptions of new forms. Bijdr. Dierkd. 35.

Géry, J., 1977. Characoids of the World. TFH Publications, Neptune City.

Harris, S.E., Mix, A.C., 2002. Climate and tectonic influences on continental erosion of tropical South America, 0-13 Ma. Geology 30, 447-450. http://dx.doi.org/ 10.1130/0091-7613(2002)030.

Hebert, P.D.N., Cywinska, A., Ball, S.L., DeWaard, J.R., 2003. Biological identifications through DNA barcodes. Proc. R. Soc. B: Biol. Sci. 270, 313-321. http://dx.doi.org/ 10.1098/rspb.2002.2218.

Hoorn, C., 1993. Marine incursions and the influence of Andean tectonics on the Miocene depositional history of northwestern Amazonia: results of a palynostratigraphic study. Palaeogeogr. Palaeoclimatol. Palaeoecol. 105, 267309. http://dx.doi.org/10.1016/0031-0182(93)90087-Y.

Hoorn, C., Wesselingh, F.P., ter Steege, H., Bermudez, M.A., Mora, A., Sevink, J., Sanmartín, I., Sanchez-Meseguer, A., Anderson, C.L., Figueiredo, J.P., Jaramillo, C., Riff, D., Negri, F.R., Hooghiemstra, H., Lundberg, J., Stadler, T., Särkinen, T., Antonelli, A., 2010. Amazonia through time: Andean uplift, climate change, landscape evolution, and biodiversity. Science 330, 927-931. http://dx.doi.org/ 10.1126/science. 1194585

Hubert, N., Duponchelle, F., Nuñez, J., Garcia-Davila, C., Paugy, D., Renno, J.F., 2007. Phylogeography of the piranha genera Serrasalmus and Pygocentrus: implications for the diversification of the Neotropical ichthyofauna. Mol. Ecol. 16, 2115-2136. http://dx.doi.org/10.1111/j.1365-294X.2007.03267.x.

Hubert, N., Renno, J.-F., 2006. Historical biogeography of South American freshwater fishes. J. Biogeogr. 33, 1414-1436. http://dx.doi.org/10.1111/j.13652699.2006.01518.x.

Javonillo, R., Malabarba, L.R., Weitzman, S.H., Burns, J.R., 2010. Relationships among major lineages of characid fishes (Teleostei: Ostariophysi: Characiformes), based on molecular sequence data. Mol. Phylogenet. Evol. 54, 498-511. http:// dx.doi.org/10.1016/j.ympev.2009.08.026.

Kearse, M., Moir, R., Wilson, A., Stones-Havas, S., Cheung, M., Sturrock, S., Buxton, S., Cooper, A., Markowitz, S., Duran, C., Thierer, T., Ashton, B., Meintjes, P., Drummond, A., 2012. Geneious Basic: an integrated and extendable desktop software platform for the organization and analysis of sequence data. Bioinformatics 28, 1647-1649. http://dx.doi.org/10.1093/bioinformatics/ bts199.

Li, C., Lu, G., Ortí, G., 2008. Optimal data partitioning and a test case for ray-finned fishes (Actinopterygii) based on ten nuclear loci. Syst. Biol. 57, 519-539. http:// dx.doi.org/10.1080/10635150802206883.

Li, C., Ortí, G., Zhang, G., Lu, G., 2007. A practical approach to phylogenomics: the phylogeny of ray-finned fish (Actinopterygii) as a case study. BMC Evol. Biol. 7, 44. http://dx.doi.org/10.1186/1471-2148-7-44.

Lima, F.C.T., Malabarba, L., Buckup, P., Pezzi da Silva, J., Vari, R.P., Harold, A.S., Benine, R.C., Oyakawa, O., Pavanelli, C.S., Menezes, N.A., Lucena, C.A.S., Malabarba, M.C.S.L., Lucena, Z.M.S., Reis, R.E., Langeani, F., Cassati, L., Bertaco, V.A., Moreira, C., Lucinda, P.H.F., 2003. Characidae, genera incertae sedis. In:
Reis, R.E., Kullander, S., Ferraris, C.J. (Eds.), Check List of the Freshwater Fishes of South and Central America. Edipucrs, Porto Alegre, p. 729.

Lima, F.C.T., Ribeiro, A.C., 2011. Continental-scale tectonic controls of biogeography and ecology. In: Albert, J.S., Reis, R.E. (Eds.), Historical Biogeography of Neotropical Freshwater Fishes. University of California Press, Berkeley and Los Angeles, pp. 145-164.

Lima, M.R., Salard-Cheboldaeff, M., Suguio, K., 1985. Etude palynilogique de la formation Tremembé, Tertiaire du Bassin de Taubaté, (Etat de São Paulo, Bresil), d'apres les echantillons du sondage n-42 du CNP. Coletânea Trab. Paleontológicos, MME-DNPM. Sér Zool., vol. 27, pp. 379-393.

Lovejoy, N.R., Collette, B.B., 2001. Phylogenetic relationships of new world needlefishes (Teleostei: Belonidae) and the biogeography of transitions between marine and freshwater habitats. Copeia 1, 324-338.

Lundberg, J.G., Marshall, L., Guerrero, J., Horton, B., Malabarba, M.C.S.L., Wesselingh, F., 1998. The stage for Neotropical fish diversification: a history of tropical South American rivers. In: Malabarba, L.R., Reis, R.E., Vari, R.P., Lucena, Z., Lucena, C. (Eds.), Phylogeny and Classification of Neotropical Fishes. Edipucrs, Porto Alegre, pp. 13-48.

Malabarba, M.C.S.L., 1998. Phylogeny of fossil Characiformes and paleobiogeography of the Tremembé Formation, São Paulo, Brazil. In: Malabarba, L.R., Reis, R.E., Vari, R.P., Lucena, Z.M.S., Lucena, C.A.S. (Eds.), Phylogeny and Classification of Neotropical Fishes. Edipucrs, Porto Alegre, pp. 69-84.

Mariguela, T.C., Ortí, G., Avelino, G.S., Abe, K.T., Oliveira, C., 2013. Composition and interrelationships of a large Neotropical freshwater fish group, the subfamily Cheirodontinae (Characiformes: Characidae): a case study based on mitochondrial and nuclear DNA sequences. Mol. Phylogenet. Evol. 68, 23-34. http://dx.doi.org/10.1016/j.ympev.2013.03.011.

Mattox, G.M.T., Toledo-Piza, M., 2012. Phylogenetic study of the Characinae (Teleostei: Characiformes: Characidae). Zool. J. Linn. Soc. 165, 809-915. http://dx.doi.org/10.1111/j.1096-3642.2012.00830.x.

Melo, B.F., Benine, R.C., Mariguela, T.C., Oliveira, C., 2011. A new species of Tetragonopterus Cuvier, 1816 (Characiformes: Characidae: Tetragonopterinae) from the rio Jari, Amapá, northern Brazil. Neotrop. Ichthyol. 9, 49-56.

Miller, M., Pfeiffer, W., Schwartz, T., 2010. Creating the CIPRES science gateway for inference of large phylogenetic trees. In: Proceedings of the Gateway Computing Environments Workshop (GCE), New Orleans, LA, pp. 1-8.

Mirande, J.M., 2010. Phylogeny of the family Characidae (Teleostei: Characiformes): from characters to taxonomy. Neotrop. Ichthyol. 8, 385-568.

Oliveira, C., Avelino, G.S., Abe, K.T., Mariguela, T.C., Benine, R.C., Ortí, G., Vari, R.P., Corrêa e Castro, R.M., 2011. Phylogenetic relationships within the speciose family Characidae (Teleostei: Ostariophysi: Characiformes) based on multilocus analysis and extensive ingroup sampling. BMC Evol. Biol. 11, 275. http://dx.doi. org/10.1186/1471-2148-11-275.

Palumbi, S., 1996. Nucleic acids II: the polymerase chain reaction. In: Hillis, D., Moritz, C., Mable, B. (Eds.), Molecular Systematics. Sinauer Associates Inc., Massachussetts, pp. 205-247.

Parham, J.F., Donoghue, P.C.J., Bell, C.J., Calway, T.D., Head, J.J., Holroyd, P.A., Inoue, J. G., Irmis, R.B., Joyce, W.G., Ksepka, D.T., Patané, J.S.L., Smith, N.D., Tarver, J.E., van Tuinen, M., Yang, Z., Angielczyk, K.D., Greenwood, J.M., Hipsley, C.A., Jacobs, L., Makovicky, P.J., Müller, J., Smith, K.T., Theodor, J.M., Warnock, R.C.M., Benton, M J., 2012. Best practices for justifying fossil calibrations. Syst. Biol. 61, 346-359. http://dx.doi.org/10.1093/sysbio/syr107.

Posada, D., Buckley, T.R., 2004. Model selection and model averaging in phylogenetics: advantages of akaike information criterion and bayesian approaches over likelihood ratio tests. Syst. Biol. 53, 793-808. http://dx.doi. org/10.1080/10635150490522304.

Rambaut, A., Suchard, M.A., Xie, D., Drummond, A.J., 2014. Tracer v1.6. <http://beast. bio.ed.ac.uk/Tracer>.

Reis, R.E., 2003. Subfamily Tetragonopterinae. In: Reis, R.E., Kullander, S.O., Ferraris C.J. (Eds.), Check List of the Freshwater Fishes of South and Central America. Edipucrs, Porto Alegre, p. 212

Reis, R.E., Kullander, S.O., Ferraris, C.J., 2003. Check List of the Freshwater Fishes of South and Central America. Edipucrs, Porto Alegre, 729 p.

Ribeiro, A.C., Jacob, R.M., Silva, R.R.S.R., Lima, F.C.T., Ferreira, D.C., Ferreira, K.M., Mariguela, T.C., Pereira, L.H.G., Oliveira, C., 2013. Distributions and phylogeographic data of rheophilic freshwater fishes provide evidences on the geographic extension of a central-Brazilian amazonian palaeoplateau in the area of the present day Pantanal Wetland. Neotrop. Ichthyol. 11, 319-326. http://dx.doi.org/10.1590/S1679-62252013000200010.

Riccomini, C., Suguio, K., Alvarenga, H., Fittipaldi, F., 1991. Estratigrafia e ambientes de sedimentação da porção central da Bacia de Taubaté. In: Congresso Brasileiro de Paleontologia, pp. 12, 1-29.

Sabaj Pérez, M.H., 2013. Standard Symbolic Codes for Institutional Resource Collections in Herpetology and Ichthyology. Am. Soc. Ichthyol. Herpetol. <http://www.asih.org>.

Silva, G.S.C., Benine, R.C., 2011. A new species of Tetragonopterus Cuvier, 1816 (Characiformes, Characidae, Tetragonopterinae) from the upper rio Araguaia Central Brazil. Zootaxa 2911, 50-56.

Silva, G.S.C., Melo, B.F., Oliveira, C., Benine, R.C., 2013. Morphological and molecular evidence for two new species of Tetragonopterus (Characiformes: Characidae) from central Brazil. J. Fish Biol. 82, 1613-1631. http://dx.doi.org/10.1111/ jfb.12094.

Sivasundar, A., Bermingham, E., Ortí, G., 2001. Population structure and biogeography of migratory freshwater fishes (Prochilodus: Characiformes) in major South American rivers. Mol. Ecol. 10, 407-417. 
Soares, P.C., Assine, M.L., Rabelo, L., 1998. The Pantanal Basin: recent tectonics, relationships to the Transbrasiliano Lineament. In: Anais IX Simpósio Brasileiro de Sensoriamento Remoto, pp. 459-469.

Soria, M.F., Alvarenga, H., 1989. Nuevos restos de mamiferos de la Cuenca de Taubaté, Estado de São Paulo, Brasil. An. Acad. Bras. Ciências 61, 157-175.

Stamatakis, A., 2006. RAxML-VI-HPC: maximum likelihood-based phylogenetic analyses with thousands of taxa and mixed models. Bioinformatics 22, 2688 2690.

Stamatakis, A., Hoover, P., Rougemont, J., 2008. A rapid bootstrap algorithm for the RAxML web servers. Syst. Biol. 57, 758-771.

Tagliacollo, V.A., Souza-Lima, R., Benine, R.C., Oliveira, C., 2012. Molecular phylogeny of Aphyocharacinae (Characiformes, Characidae) with morphological diagnoses for the subfamily and recognized genera. Mol Phylogenet. Evol. 64, 297-307. http://dx.doi.org/10.1016/j.ympev.2012.04.007.

Tamura, K., Peterson, D., Peterson, N., Stecher, G., Nei, M., Kumar, S., 2011. MEGA5: molecular evolutionary genetics analysis using maximum likelihood, evolutionary distance, and maximum parsimony methods. Mol. Biol. Evol. 28, 2731-2739. http://dx.doi.org/10.1093/molbev/msr121.
Taylor, W., Van Dyke, G., 1985. Revised procedures for staining and clearing small fishes and other vertebrates for bone and cartilage. Cybium 9, 107119.

Thomaz, A.T., Arcila, D., Ortí, G., Malabarba, L.R., 2015. Molecular phylogeny of the subfamily Stevardiinae Gill, 1858 (Characiformes: Characidae): classification and the evolution of reproductive traits. BMC Evol. Biol., 6-8 http://dx.doi.org/ 10.1186/s12862-015-0403-4.

Weitzman, S.H., 1974. Osteology and evolutionary relationships of the Sternoptychidae with a new classification of stomiatoid families. Bull. Am. Mus. Nat. Hist. 153, 327-478.

Wesselingh, F.P., Hoorn, C., 2011. Geological development of Amazon and Orinoco basins. In: Albert, J.S., Reis, R.E. (Eds.), Historical Biogeography of Neotropical Freshwater Fishes. University of California Press, Berkeley and Los Angeles, pp. 59-67.

Xia, X., 2013. DAMBE5: a comprehensive software package for data analysis in molecular biology and evolution. Mol. Biol. Evol. 30, 1720-1728. http://dx.doi. org/10.1093/molbev/mst064. 